\title{
Management of COVID-19 on board the mixed cargo ship Aranui 5
}

\author{
Jean-Claude Chatard ${ }^{1}\left(\mathbb{D}\right.$, Jean-Marc Le Gac ${ }^{2}$, Sylvie Gonzalo ${ }^{3}$, Philippe Vaysse ${ }^{4}$, Mathieu Coulange ${ }^{5}$ \\ ${ }^{1}$ Faculty of Medicine Jacques Lisfranc, University Lyon-Saint-Etienne, France \\ ${ }^{2}$ Health Simulation Centre of Scorff, Group, C3S-Groupe Hospitalier of Bretagne sud, Lorient, France \\ ${ }^{3}$ Centre Hospitalier Universitaire de Saint-Etienne, Saint-Etienne, France \\ ${ }^{4}$ Medical Department of Aranui 5, Raiatéa, French Polynesia \\ ${ }^{5}$ Assistance Publique Hôpitaux de Marseille, Marseille, France
}

\begin{abstract}
Background: During cruises, the management of coronavirus disease 2019 (COVID-19) infections poses serious organizational problems such as those encountered in 2020 by the Zaandam, the aircraft carrier Charles de Gaulle or the Diamond Princess. In French Polynesia, the mixed cargo ship Aranui 5 transports both tourists and freight to the Marquesas Islands. The purpose of this article is to show how COVID-19 infections were diagnosed and contained before and after passengers boarded a cruise.

Materials and methods: On October 15, 2020, 161 passengers including 80 crew members embarked for a 13-day voyage from Papeete to the Marquesas Islands. Prior to boarding, all passengers underwent a reverse transcriptase-polymerase chain reaction (RT-PCR) test; the tests results were all negative. On Day 0, 3, 5, 8 and 11, Biosynex ${ }^{\circledR}$ rapid antigen diagnostic tests were carried out on all or some of the crew members and tourists who may have had contact with new positive cases. Each day, forehead or temporal temperatures were measured using an infrared thermometer and questions were asked concerning the subjects' health status. When a subject was positive, the person and their contacts were isolated in individual cabins. The infected person then left the vessel to be received in a communal reception centre on the nearest island.

Results: A total of 9 positive cases were observed, including two before departure (a tourist and a crew member). During the trip, $7 \mathrm{crew}$ members tested positive. The patients and their contacts were isolated and then disembarked at the earliest opportunity. At the time of sampling, the subjects were asymptomatic. The patients and their contacts all became symptomatic within 24 to 48 hours after sampling. Conclusions: In total, the voyage could be completed without any transmission on board among the tourists and with a minimum transmission among the crew members, thus maintaining the tourist and economic activity of the islands during the times of COVID-19 pandemic.
\end{abstract}

(Int Marit Health 2021; 72, 3: 155-162)

Key words: cruise, crew members, French Polynesia, rapid antigenic diagnostic orientation tests, reverse transcriptase-polymerase chain reaction (RT-PCR), virus infection

\section{INTRODUCTION}

During cruises, the management of coronavirus disease (COVID-19) infections poses serious organizational problems such as those encountered in 2020 by the Zaandam, the Celebrity Apex, the aircraft carrier Charles de Gaulle or the
Diamond Princess. In February 2020, a total of 634 cases of COVID-19 were detected aboard the Diamond Princess among 3,711 passengers forcing the ship to remain in dock for 4 weeks in quarantine in Yokohama, Japan [1-3]. On the Zaandam, after a few days into the cruise 54 of the

Prof. Jean-Claude Chatard, Service de Physiologie Clinique et de l'Exercice, CHU de Saint-Etienne, 42055 Saint-Etienne cedex 2, tel/fax: +33664516017,

e-mail: chatard@univ-st-etienne.fr

This article is available in open access under Creative Common Attribution-Non-Commercial-No Derivatives 4.0 International (CC BY-NC-ND 4.0) license, allowing to download articles and share them with others as long as they credit the authors and the publisher, but without permission to change them in any way or use them commercially. 
Table 1. Health facilities on the islands located on the Aranui's route to the Marquesas

\begin{tabular}{|c|c|c|c|c|}
\hline Islands & Infirmary & Medical centre & Pharmacy & Local hospital \\
\hline Fakarava & $x$ & & & \\
\hline Rangiroa & & $x$ & $x$ & \\
\hline Bora bora & & $x$ & $x$ & \\
\hline Nuku Hiva & & $x x$ & $x$ & $x$ \\
\hline Hiva Oa & & $x$ & $x$ & \\
\hline Fatu Hiva & $x$ & & & \\
\hline Ua Pou & & $x$ & $x$ & \\
\hline Ua Huka & $x$ & & & \\
\hline Tahuata & $x$ & & & \\
\hline
\end{tabular}

1,800 passengers on board were confirmed positive and 4 passengers died. On the Charles de Gaulle, $70 \%$ of the 1,760 crew on board were found to be infected.

In French Polynesia, many cruise ships visit the 118 islands spread over an area the size of Europe. Polynesia has many dispensaries but only 4 hospitals, including only one in the Marquesas Islands on the main island of Nuku Hiva (Table 1). Only the Papeete Hospital Centre is equipped to accommodate patients with COVID-19, with 200 beds, including 40 COVID-19 beds among the 60 intensive care beds.

October 15, 2020 was the departure date of cruise 16 of the Aranui 5 from Papeete to the Marquesas. At this time, the COVID-19 pandemic was at its highest in Polynesia with an incidence rate of around 500 cases per 100,000 people and a reproduction rate of 1.4 . During the 3 months preceding the departure, of the total number of 280,000 inhabitants 3,735 people were infected and 14 died from COVID-19. Many of the infected patients had different comorbidities, e.g.: overweight, diabetes and high blood pressure. Additionally, a communal lifestyle of the local people, i.e. living in close proximity to one another facilitated the spread of infection.

The mixed cargo ship Aranui 5 carries both tourists and freight to the Marquesas Islands (Figs. 1, 2). The total duration of the cruise is 13 days. Usually, half of the passengers are Polynesians and the other half are tourists from abroad. On October 15, the occupancy rate was around $50 \%$ with only few Western/British tourists due to the travel restrictions imposed because of the pandemic.

The crew was made up mostly of Marquesans. The majority had been confined on board since the date of their last voyage, 20 days earlier, but a few had had contact outside the vessel at the dockside. The previous cruise had been cancelled for tourists but maintained for freight. Twelve crew members had tested positive, including the captain and his first officer, forcing the vessel to return to port after just 1 day of travel. All of the new crew had tested negative and were ready to depart on cruise 16 .

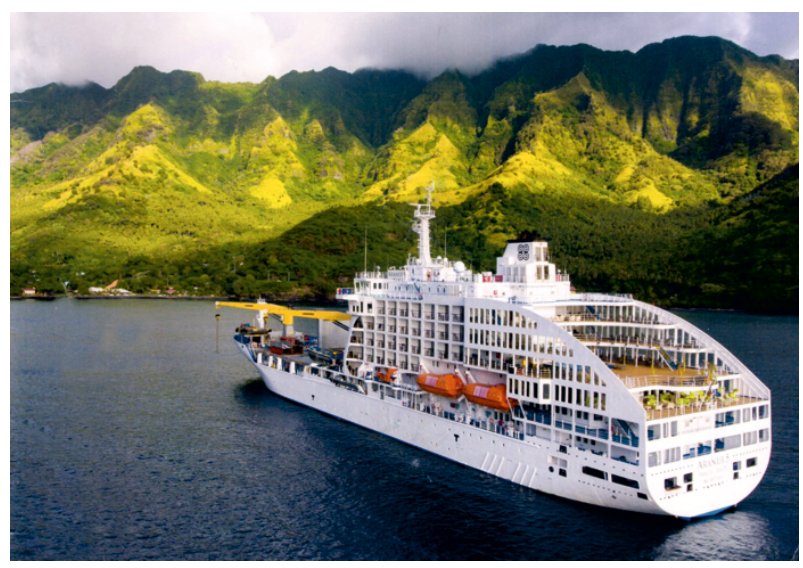

Figure 1. The Aranui 5 is a mixed cargo ship that carries both cruise tourists and cargo to the Marquesas Islands

The purpose of this article is to show how COVID-19 infections were diagnosed and therefore contained before and after embarking on a cruise to the Marquesas on the mixed cargo ship Aranui 5.

\section{MATERIALS AND METHODS MEDICAL ORGANIZATION ON BOARD}

The vessel accommodates a maximum of 335 passengers, including 225 tourists and 110 crew members. In accordance with international regulations, it is equipped with an infirmary with two hospital rooms, resuscitation equipment including a defibrillator, a portable respirator, intubation equipment, transportable oxygen bottles and medical bags for shore excursions each containing a defibrillator.

A ship's doctor and a nurse are delegated to manage medical emergencies and monitor the health of those on board. The doctor is the captain's primary consultant for any particular medical intervention. The medical team is reinforced by 4 crew members of the kitchen staff trained in first aid in the event of a medical emergency. 


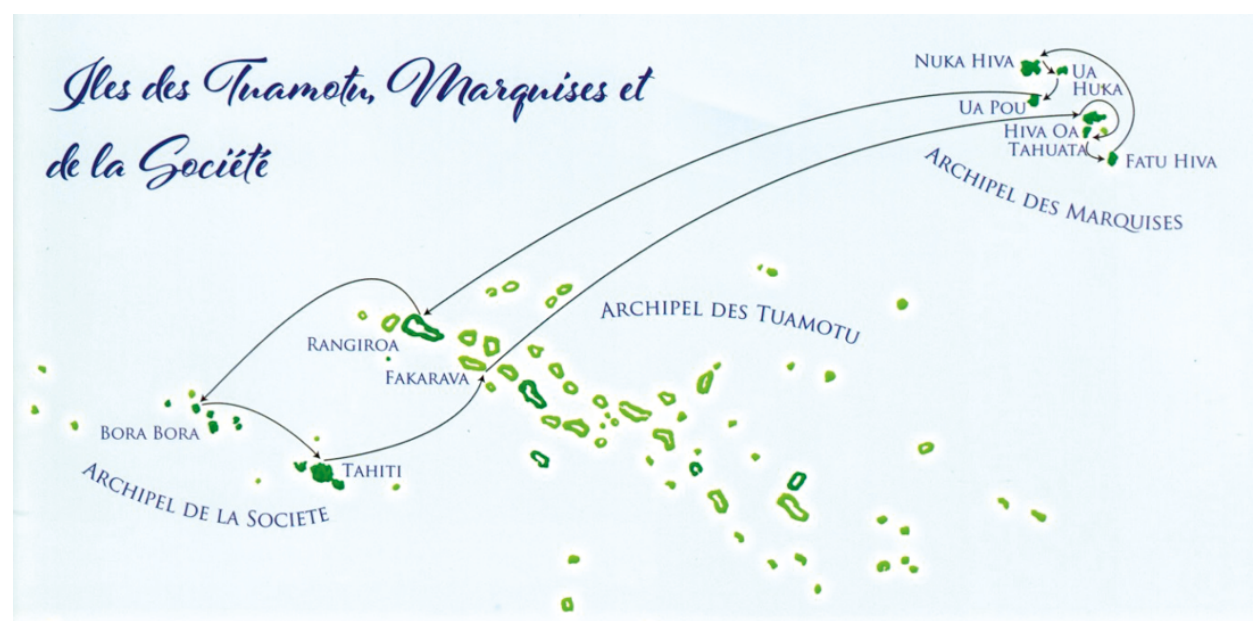

Figure 2. Aranui 5 cruise with stops from Papeete to the Marquesas via the Tuamotu and Society archipelagos

During Aranui 5 cruises, the regulation equipment on board (division D217) is supplemented by sets of personal protective equipment, but also 300 Biosynex ${ }^{\circledR}$ antigen diagnostic tests giving results in a few minutes.

On October 15, the Aranui 5 welcomed 161 passengers, including 81 tourists and 80 crew members, amounting to around $50 \%$ of her maximum capacity.

\section{CONTROL OF COVID-19}

Before boarding. All local tourists had taken a reverse transcriptase-polymerase chain reaction (RT-PCR) test 2-3 days before boarding in line with the Polynesian regulations; the tests results were all negative. The other tourists coming from metropolitan France or from abroad had presented a negative RT-PCR result on the test taken 3 to 7 days before their departure. They had to take another self-collected RT-PCR test 4 days after their arrival in the country. This could correspond to the day before or even to the very day of the departure at sea. The results of these tests were not known. Therefore, Biosynex ${ }^{\circledR}$ rapid antigen tests were carried out either the day before or immediately before departure.

All new crew members had had a negative RT-PCR test result 3 days before departure. A total of 27 crew members who had tested negative on the previous trip and were staying on board were not screened as it was considered unnecessary.

After boarding. For all crew members, a one way testing pathway for Biosynex ${ }^{\circledR}$ rapid antigen tests had been prepared on the aft deck of the vessel by the nurse and the on-board doctor. Crew members were duly summoned and their identity confirmed by the captain or the first officer.

Upon embarkation, temporal or frontal temperatures were measured using an infrared thermometer and questions were asked regarding their general condition. A test number was assigned to each person. The nurses of the private company Moana Médex as well as the one on board, took samples with a successive deep swab of both nostrils. The crew members remained on the aft deck until the results were given by the doctor and then they returned to their work following a one way circuit to avoid contact with other crew members (Fig. 3).

To improve the efficiency of the measurements, each tube was numbered from 1 to 80 , with a different colour code for a set of 5 samples. This made it possible to successively conduct 4 series of 5 samples. Timers were set off after each batch of 5 tests. All the results were collated in a spreadsheet. When a subject was tested positive, he was isolated in an individual cabin as well as the people considered to be his contacts, even if they tested negative.

During the trip. Every morning, the temporal or frontal temperature of crew members was checked by the nurse using an infrared thermometer. That of tourists was measured before each meal, using a thermal sensor installed at the entrance to the restaurant (Fig. $3 \mathrm{C}$ ) and also before each visit ashore.

On Day 3, 5, 8 and 11, further rapid antigen tests were carried out by the nurse and the on-board doctor on all or some of the crew members who may have had contact with the new positive cases. The tourists did not undergo any further tests except when they were symptomatic, as recommended by the cruise company.

\section{BEFORE LEAVING}

\section{RESULTS}

Two RP-PCR tests were positive in one of the 81 tourists and one of the 53 crew members. The crew member had had contact with 3 sailors who were working ashore at the embarkation and disembarkation of cargo. Both subjects were asymptomatic. They were excluded from the trip and were not allowed to get on board. The tourist who tested 

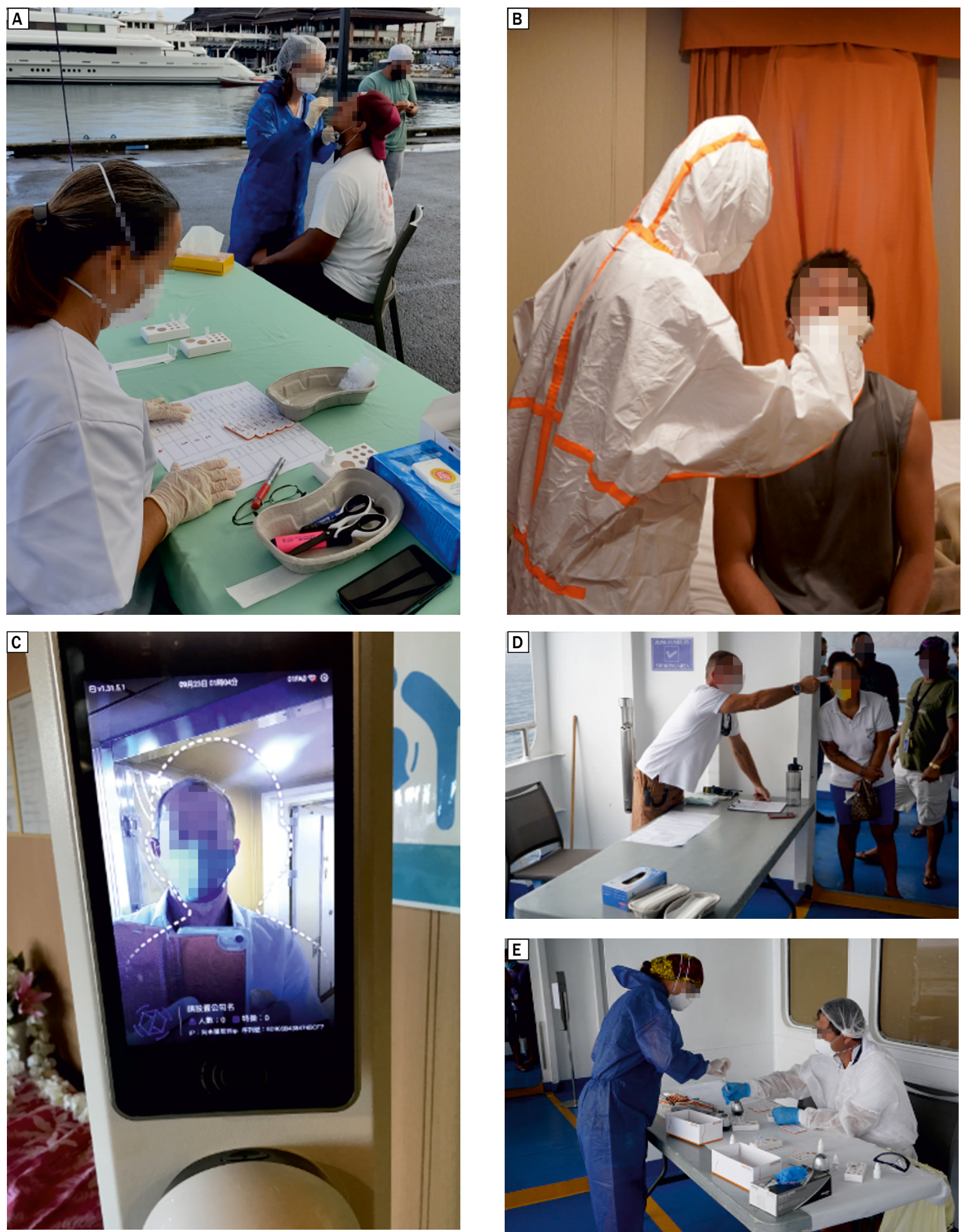

Figure 3. Nasopharyngeal samples taken on land (A) and in the cabin (B). Whole body (C) or temporal (D) temperature measurements, rapid analysis test $(\mathbf{E})$ 
Table 2. Date of sampling, number of people involved and decision taken for those testing positive and contact cases

\begin{tabular}{|c|c|c|c|}
\hline & N subjects tested & Positive subjects & Decision \\
\hline $\begin{array}{l}\text { D0 } \\
15 \text { October } \\
\text { Before ship's departure }\end{array}$ & $\begin{array}{l}81 \text { tourists } \\
35 \text { crew members }\end{array}$ & $\begin{array}{l}1 \text { case } \\
1 \text { case }\end{array}$ & $\begin{array}{l}1 \text { couple and } 1 \text { crew member did not } \\
\text { embark }\end{array}$ \\
\hline $\begin{array}{l}\text { D3 } \\
18 \text { October }\end{array}$ & 79 crew members & $\begin{array}{l}1 \\
43 \text {-year-old man }\end{array}$ & $\begin{array}{l}\text { Isolated together with } 2 \text { cabin contacts. } \\
\text { All disembarked on Hiva Oa to the } \\
\text { isolation centre }\end{array}$ \\
\hline $\begin{array}{l}\text { D5 } \\
20 \text { October }\end{array}$ & 76 crew members & $\begin{array}{l}1 \\
\text { 36-year-old lieutenant with } \\
\text { duties in the engine room }\end{array}$ & Disembarked on Nuku Hiva \\
\hline $\begin{array}{l}\text { D8 } \\
23 \text { October }\end{array}$ & $\begin{array}{l}16 \text { workers in the engine } \\
\text { room and gangway and the } \\
6 \text { staying/accommodated } \\
\text { in the same corridor }\end{array}$ & $\begin{array}{l}1 \\
\text { 36-year-old machine room } \\
\text { operator }\end{array}$ & $\begin{array}{l}\text { Disembarked on Nuku Hiva. } \\
\text { The } 2 \text { contact cases remained on board } \\
\text { in isolation }\end{array}$ \\
\hline $\begin{array}{l}\text { D11 } \\
26 \text { October }\end{array}$ & $\begin{array}{l}\text { Case testing of contacts with } \\
\text { clinical symptoms }\end{array}$ & $\begin{array}{l}2 \\
32 \text { - and } 37 \text {-year-old men }\end{array}$ & $\begin{array}{l}\text { Disembarked at Papeete then isolation } \\
\text { at home }\end{array}$ \\
\hline
\end{tabular}

positive had come to Papeete together with his wife and had been staying with his family for the previous 5 days. His wife, although she tested negative, was not allowed on board as well.

\section{DURING THE TRIP}

On Day 3 among all 79 crew members, a 43-year-old man tested positive. He was isolated in a single cabin, as were 2 sailors aged 40 and 65 who shared his cabin, considered as contact cases. They all disembarked 24 hours later in the Marquesas at the Hiva Oa island containment centre. The 2 crew members subsequently tested positive. The 65-year-old sailor had a history of complete cardiac arrhythmia due to atrial fibrillation and required oxygen therapy at a rate of $2 \mathrm{~L} / \mathrm{min}$ on the $5^{\text {th }}$ day after disembarkation.

On Day 5, of the remaining 76 crew members, a 36-yearold lieutenant working in the engine room tested positive, he immediately disembarked in the Marquesas Islands on Nuku Hiva Island.

Later, another 4 samples were found to be positive. However, the transmission mode could not be established and as one of the positive patients had already had COVID-19 2 months before, the subjects were immediately re-sampled and this time tested negative suggesting false positive results by contamination of the collection tubes. While handling the swabs, the operator's gloves were not changed. All 4 crew members remained on board.

On Day 8, a new screening was conducted; this time targeted at 16 crew members who had had contact with the 36-year-old man working in the engine room and on the bridge, and the 6 crew members staying in the cabins in the same corridor and also the engine room. A 36-year-old man, was an operator working in the engine room and living in the cabin next to the crew member who had tested positive at the previous screening and disembarked on Nuku Hiva Island in the Marquesas. Two contact cases from his cabin were placed in separate cabins and remained on board.

The crew members who tested positive (on day $3,5,8$ ) were asymptomatic at sampling but became symptomatic after 24 to 48 hours of sample collection.

On day 11, the 2 contact cases aged 32 and 37 , who had been placed in separate cabins, became symptomatic complaining of headaches, fever and asthenia; both had positive test results. As the end of the trip was only 48 hours away, they were allowed to stay on board and disembarked on day 13 in Papeete and were then placed in isolation at home.

In total, 7 crew members tested positive during the trip. Before departure, one crew member and one tourist had also tested positive (Table 2).

The self-tests which tourists are required to perform, carried out on the $4^{\text {th }}$ day of arrival on Polynesian territory or just before boarding, were deposited at the Nuku Hiva Hospital, after 6 days of sea travel. Analysed on site, they were all negative.

Of the crew who attended the infirmary, two presented with sore throat, which could have been attributed to exposure to air conditioning. Their antigen tests were negative.

The tourists remained asymptomatic and received no further testing.

\section{DISCUSSION}

The most important point of this study was to show that the sensitivity of rapid antigenic tests was sufficient for the detection of contagious individuals (including 8 crew members and one tourist) and their use prevented transmission of the COVID-19 infection among the 161 passengers who 
boarded the ship. These tests were therefore effective in detecting asymptomatic subjects and above all necessary to avoid the spread of infection to all passengers as had been the case with the Diamond Princess cruise ship [1-3] or on the aircraft carrier Charles de Gaulle. On this warship, the cabins were dormitories for 40 people, the passageways were very narrow and it was impossible to enforce distancing measures.

\section{DETERMINATION OF CONTAGIOUSNESS}

After contact with infected individuals, incubation of COVID-19 lasts an average of 4 to 5 days; (range between 2 and 14 days with a confidence interval of $97.5 \%$ at 12 days [4]). Right after becoming infected, the tests remain negative for several days, which is how long it takes the virus to proliferate and for the viral load to be sufficient to become detectable on the test. Infected subjects usually become contagious 2 to 3 days before the onset of symptoms. Infectiousness decreases sharply on days 7 and 8 [5]. But in the elderly and in immuno-compromised subjects it can last up to 3 weeks or even longer. In the case of the Aranui 5 ship, the contact cases were tested every 3 days [2] and the infected or sick subjects were isolated in a cabin, or disembarked at the earliest opportunity to be quarantined at a communal containment centre on the islands of Hiva Oa or Nuku Hiva or at home following the World Health Organization (WHO) recommendations [6, 7].

The investigation into the epidemic on Aranui 5 revealed that transmission first took place whilst the vessel was still in dock. Certain crew members had not followed the confinement guidelines and had conversations with other sailors and their families.

Subsequently, the transmission took place on board. In fact, all contacts sharing the same cabin tested positive and eventually became symptomatic. The positive results on rapid antigenic tests were later confirmed ashore by RT-PCR tests considered to be more reliable [5]. On the Diamond Princess, $1 / 3$ of the positive cases had remained asymptomatic over a period of 14 days [3] although they presented radiologically unequivocal pulmonary signs of COVID-19 showing that many infected subjects and patients may still have had no symptom $[2,8]$. On the Aranui 5 , it was not possible to X-ray the passengers or to test all the tourists. The total number of asymptomatic cases cannot therefore be ascertained.

The Biosynex ${ }^{\circledR}$ rapid antigenic diagnostic tests turned out to be effective. Their sensitivity between $90 \%$ and $100 \%$ and specificity between $70 \%$ and $99 \%$ have been shown to be similar to RT-PCR tests [9-11]. False negatives were rare. Most often, they resulted from non-compliance with sample collection procedures, e.g. poorly taken nasopharyngeal swabs, the swab not reaching the back of the nostrils. They can also be attributable to collecting the samples too early when the viral load is not yet sufficient to be detectable. In such cases, it suffices to repeat the tests to determine whether or not a person is infected [12]. The salivary or nasopharyngeal self-tests are easier to use, but their sensitivity is debated. For some researchers, it is high enough [13] while for others it is not [14]. This type of tests was not available on the Aranui 5.

The 4 false positives were detected very quickly after a re-test. They probably have been linked to contamination during handling of samples from the first positive case as observed under other conditions by Esteve et al. (2020) [15]. Then, the person conducting the test sanitised his hands and used a new pair of gloves as often as possible. Although the tests on Aranui 5 were carried out by a small team and in a timeframe constrained by the crew's work, 80 tests were carried out in 2 hours 30 minutes during the first session, subsequently 79 tests in 1 hour 30 minutes during the second session. Positive results appeared in less than 2 minutes and consolidated in 15 minutes.

Also considered as false positives are the tests whose viral load is sufficient to be detected but insufficient to contaminate such as for example after recovery. The tests remain positive for a few days without the subject being contagious [15].

\section{MODE OF TRANSMISSION}

Apart from non-compliance with containment instructions, non-compliance with preventive measures on board was also observed in the cabins, in the restaurant and in the crew's rest rooms.

Crew members lived 2 to 3 in a cabin. Distancing more than one metre to avoid getting infected by saliva droplets was impossible [16]. The contact time was long, greater than the 15-25 minutes - which is the time required for transmission to take place without a mask in a closed, unventilated environment [17]. In practice, all contact cases staying in the same cabin became therefore infected as in the case of the Diamond Princess [1]. However, there was one exception: the case of the lieutenant who was staying in an isolated cabin which adjoined the cabin of the first case detected on board. The transmission could be explained either by the contact with touch surfaces (hand rails) or transmission via the ventilation system (the lack of ventilation to the outside).

In total, special attention was therefore paid to the crew members staying in the cabins in the corridor where the first cases had been discovered. The ship owner has decided to introduce the following measures on the trips to follow: (i) to favour 2-person cabins, bringing together crew members already living together on land, (ii) to hire crew who have recovered from COVID-19 and are therefore immunised, 
(iii) to complement the systems of air conditioning with UV systems and other antimicrobial devices, such as filters [18].

The crew and the tourists were not completely separated from one another while eating in a restaurant or staying in the rest room. On the Diamond Princess, this was the main site of contamination [1]. The solution then was to wear a mask, the value of which has been well demonstrated inside a closed, unventilated room [19]. But on the Aranui 5, people did not fully respect the requirement to wear face masks. It was sometimes worn improperly, i.e. not covering the nose. Duck bill masks have also been reported to interfere with breathing in the engine room where the temperature can reach $40^{\circ} \mathrm{C}$. From this observation, better tolerated surgical masks were made available to the crew.

Communication between the medical team, the captain, his first officer, passengers, other crew members and the owner was maintained on a regular basis. Test results and modes of transmission were explained in full transparency. The aim was for everyone to increase their awareness and start using preventive measures. The following issues were raised during the discussions with the crew: the risks of transmission in the crew's passageways by touching the guardrails, or the clothes placed on the guardrails, the risks from sharing bottles or drinks. Following the discussions, hand sanitizer dispensers were installed, clearly following in this the recommendations of Pradhan et al. [20]. Also, the negativity of the tests was explained and any rumours were ruled out. Part of the crew, for example, believed that regular ingestion of kava, a traditional slightly hallucinogenic Melanesian drink that is obtained from the roots of shrubs soaked and then squeezed [21] can prevent infection. Those who perceived themselves as immune, relaxed the preventive measures.

The preventive measures applied on the Aranui 5 since February 2020 have been explained clearly on posters and were the subject of 2 passenger briefings from the medical team.

It was recommended that everyone wash their hands several times a day [22] even though isolated hand washing is not considered sufficient to protect against getting infected [19]. Likewise, guardrails, common computer keyboards and control levers were regularly disinfected as recommended by the WHO [23]. Viruses can persist for up to 9 days on certain surfaces, but it is not clear whether the viral load they constitute is sufficient to be contaminating [22-24]. Hydro-alcoholic gel dispensers were installed in conspicuous places in resting, transition and meeting areas for passengers and crew, such as in lifts and stairways.

The control of temporal or frontal temperatures was difficult to carry out and was limited to the areas of compulsory passage: entry and exit by the ship's gangway at stopovers and entrance to the restaurant. None of the measurements were abnormal. Some crew members confessed to having taken paracetamol out of precaution, fearing they would be disembarked in case of fever!

\section{THE PSYCHOLOGICAL CONSEQUENCES}

The psychological consequences could not be effectively evaluated, but some officers were observed to have symptoms related to high mental stress, such as insomnia, back pain and high blood pressure. The crew perceived the confinement on board as a factor of exhaustion. They were looking for companionship as a way to cope with the imposed preventive measures.

On other cruise ships, several suicides have been reported following the announcement of confinements or prolonged quarantines such as on the Regal Princess or the Carnival Breeze. Following the inactivity of 3,000 cruise ships for health reasons, the Cruise Line International Association reported a clear decrease in the Seafarer Happiness Index [25], reflecting their psychological suffering.

As for tourists, maintaining group activities, such as dance and music, has effectively limited the psychological stress. Sport and relaxation activities were added by the cruise staff to the usual programme. The massage service was very busy during the cruise, but alcohol consumption did not increase.

For the medical team, discussions with the referring doctor, the health monitoring office and the cruise manager in Papeete were invaluable in assessing the risks of transmission and in managing evacuations ashore. The progression of the cases could be analysed on daily basis and the adaptation of procedures decided in consultation with the captain and the medical team.

\section{CONCLUSIONS}

Rapid antigenic screening using a deep nasal swab helped the detection of COVID-19 on Aranui 5; thus, transmission was limited to 9 , out of 161 passengers, including 8 crew members and only 1 tourist. These tests proved effective in detecting and isolating contagious asymptomatic subjects. They therefore helped prevent transmission of the infection to all passengers and allowed the continuation of the cruise and the transport of freight to the Marquesas Islands.

In addition to rapid screening tests, other decisive measures were put in place such as the separating the crew members, isolation of the infected persons and contact cases, regular disinfection of cabins, corridors and common areas, improving the provision of hydro-alcoholic gel sanitizer, introducing remote assistance for the management of the infected persons and placing them in a communal reception centre after disembarkation under the supervision of the island doctors. 
The preventive measures were reinforced and encouraged by the medical team to all the crew and tourists. Despite the effort to communicate the transmission risks and correct erroneous ideas, the fear of infection remained a stress factor. Moments of conviviality were sought to avoid moral exhaustion, sometimes with the non-compliance with confinement and preventive measures, along with the taking of antipyretics.

Discussions with the referring doctor, the health monitoring office and the cruise manager were invaluable in managing each positive case, the risks of transmission and evacuations ashore.

In summary, the cruise was able to be completed, without any transmission on board among the tourists and with a minimum of transmission among the crew members, ensuring the tourist and economic activity of the islands, during the peak of the COVID-19 pandemic.

\section{Conflict of interest: None declared}

\section{REFERENCES}

1. Kakimoto K, Kamiya H, Yamagishi T, et al. Initial Investigation of Transmission of COVID-19 Among Crew Members During Quarantine of a Cruise Ship - Yokohama, Japan, February 2020. MMWR Morb Mortal Wkly Rep. 2020; 69(11): 312-313, doi: 10.15585/mmwr.mm6911e2, indexed in Pubmed: 32191689.

2. Hung IFN, Cheng VCC, Li X, et al. SARS-CoV-2 shedding and seroconversion among passengers quarantined after disembarking a cruise ship: a case series. Lancet Infect Dis. 2020; 20(9): 1051-1060, doi: 10.1016/S1473-3099(20)30364-9, indexed in Pubmed: 32539986.

3. Tabata S, Imai K, Kawano S, et al. Clinical characteristics of COVID-19 in 104 people with SARS-CoV-2 infection on the Diamond Princess cruise ship: a retrospective analysis. Lancet Infect Dis. 2020; 20(9): 1043-1050, doi: 10.1016/S1473-3099(20)30482-5, indexed in Pubmed: 32539988.

4. Lauer SA, Grantz KH, Bi Q, et al. The Incubation Period of Coronavirus Disease 2019 (COVID-19) From Publicly Reported Confirmed Cases: Estimation and Application. Ann Intern Med. 2020; 172(9): 577-582, doi: 10.7326/M20-0504, indexed in Pubmed: 32150748.

5. van Kampen JJA, van de Vijver DA, Fraaij PLA, et al. Duration and key determinants of infectious virus shedding in hospitalized patients with coronavirus disease-2019 (COVID-19). Nat Commun. 2021; 12(1): 267 , doi: 10.1038/s41467-020-20568-4, indexed in Pubmed: 33431879.

6. Foppiani A, Bertoli S, Battezzati A, et al. Data to guide the application of the new WHO criteria for releasing COVID-19 patients from isolation. Pharmacol Res. 2020; 160: 105063, doi: 10.1016/j. phrs.2020.105063, indexed in Pubmed: 32663611.

7. WHO. Criteria for Releasing covid-19 Patients From Isolation. . https:// www.who.int/news-room/commentaries/ (2020).

8. Ooi EE, Low JG. Asymptomatic SARS-CoV-2 infection. Lancet Infect Dis. 2020; 20(9): 996-998.

9. Chaimayo C, Kaewnaphan B, Tanlieng N, et al. Rapid SARS-CoV-2 antigen detection assay in comparison with real-time RT-PCR assay for laboratory diagnosis of COVID-19 in Thailand. Virol J. 2020; 17(1): 177, doi: 10.1186/s12985-020-01452-5, indexed in Pubmed: 33187528.

10. Gambino CM, Lo Sasso B, Colomba C, et al. Comparison of a rapid immunochromatographic test with a chemiluminescence immunoassay for detection of anti-SARS-CoV-2 IgM and IgG. Biochem Med (Zagreb).
2020; 30(3): 030901, doi: 10.11613/BM.2020.030901, indexed in Pubmed: 33071558.

11. Van Honacker E, Van Vaerenbergh K, Boel A, et al. Comparison of five SARS-CoV-2 rapid antigen detection tests in a hospital setting and performance of one antigen assay in routine practice: a useful tool to guide isolation precautions? J Hosp Infect. 2021; 114: 144-152, doi: 10.1016/j.jhin.2021.03.021, indexed in Pubmed: 33785377.

12. Arevalo-Rodriguez I, Buitrago-Garcia D, Simancas-Racines D, et al. False-negative results of initial RT-PCR assays for COVID-19: A systematic review. PLoS One. 2020; 15(12): e0242958, doi: 10.1371/journal. pone.0242958, indexed in Pubmed: 33301459.

13. Pisanic N, Randad P, Kruczynski K, etal. COVID-19 serology at population scale: SARS-CoV-2-specific antibody responses in saliva. J Clin Microbiol. 2020; 59(1), doi: 10.1101/2020.05.24.20112300.

14. Nagura-Ikeda M, Imai K, Tabata S, et al. Clinical Evaluation of Self-Collected Saliva by Quantitative Reverse Transcription-PCR (RT-qPCR), Direct RT-qPCR, Reverse Transcription-Loop-Mediated Isothermal Amplification, and a Rapid Antigen Test To Diagnose COVID-19. J Clin Microbiol. 2020; 58(9), doi: 10.1128/JCM.01438-20, indexed in Pubmed: 32636214.

15. Esteve C, Catherine FX, Chavanet $P$, et al. How should a positive PCR test result for COVID-19 in an asymptomatic individual be interpreted and managed? Med Mal Infect. 2020; 50(8): 633-638, doi: 10.1016/j. medmal.2020.09.014, indexed in Pubmed: 33022291.

16. Bahl P, Doolan C, de Silva C, et al. Airborne or droplet precautions for health workers treating coronavirus disease 2019? J Infect Dis. 2020, doi: 10.1093/infdis/jiaa189.

17. Heinzerling A, Stuckey MJ, Scheuer T, et al. Transmission of COVID-19 to Health Care Personnel During Exposures to a Hospitalized Patient Solano County, California, February 2020. MMWR Morb Mortal Wkly Rep. 2020; 69(15): 472-476, doi: 10.15585/mmwr.mm6915e5, indexed in Pubmed: 32298249.

18. Morawska L, Tang JW, Bahnfleth W, et al. How can airborne transmission of COVID-19 indoors be minimised? Environ Int. 2020; 142: 105832, doi: 10.1016/j.envint.2020.105832, indexed in Pubmed: 32521345.

19. Maclntyre CR, Chughtai AA. A rapid systematic review of the efficacy of face masks and respirators against coronaviruses and other respiratory transmissible viruses for the community, healthcare workers and sick patients. Int J Nurs Stud. 2020; 108: 103629, doi: 10.1016/j. ijnurstu.2020.103629, indexed in Pubmed: 32512240.

20. Pradhan D, Biswasroy $P$, Kumar Naik $P$, et al. A review of current interventions for COVID-19 prevention. Arch Med Res. 2020; 51(5): 363-374, doi: 10.1016/j.arcmed.2020.04.020, indexed in Pubmed: 32409144.

21. Bian T, Corral $P$, Wang $Y$, et al. Kava as a clinical nutrient: promises and challenges. Nutrients. 2020; 12(10), doi: 10.3390/nu12103044, indexed in Pubmed: 33027883.

22. Bueckert M, Gupta R, Gupta A, et al. Infectivity of SARS-CoV-2 and other coronaviruses on dry surfaces: potential for indirect transmission. Materials (Basel). 2020; 13(22), doi: 10.3390/ma13225211, indexed in Pubmed: 33218120.

23. Carraturo F, Del Giudice C, Morelli M, et al. Persistence of SARS-CoV-2 in the environment and COVID-19 transmission risk from environmental matrices and surfaces. Environ Pollut. 2020; 265(Pt B): 115010, doi: 10.1016/j.envpol.2020.115010, indexed in Pubmed: 32570023.

24. Kampf G, Todt D, Pfaender S, et al. Persistence of coronaviruses on inanimate surfaces and their inactivation with biocidal agents. J Hosp Infect. 2020; 104(3): 246-251, doi: 10.1016/j.jhin.2020.01.022, indexed in Pubmed: 32035997.

25. Tedesco LM, Ferrara P, Stromillo L, et al. Seafarers' perceptions of job demand: A cross-sectional study. Arch Environ Occup Health. 2018; 73(5): 278-283, doi: 10.1080/19338244.2017.1342590, indexed in Pubmed: 28622113. 